Tire glowing sunsets having reappeared, though far less brilliant than in November and December last, I send you a list of the most remarkable of them which have been noticed at Clairvaux, in the Department of $\Lambda$ ube. They appeared with the same features as have been so often described in NATURE, and were especially glowing on the following days :-November $25,27,28$; December 12 ; January 7, 12 ; August 6, 22 (feeble, sky not quite bright), and 23 (more brilliant); September ro (feeble, bright sky, beautiful pink coloration in the east) and I 7 (bright sky, bright pink coloration one hour after sunset). When the sky is bright, the rise of the moon is preceded, for nearly one hour, by a bright illumination of the sky.

Clairvaux, Aube

P. K.

For the last four evenings, the 15 th, 16 th, 17 th, and 18 th, and again to-night, the colour of the sky from 20 to 25 minutes after sunset has taken that deep magenta glow looking very like the effect of a great fire, only lighter in tone. Last night, the 18 th, this lasted until after 7 o'clock, and stars were then shining through it as they do through an aurora.

The reappearance of these glows was to be expected, as the haze and ruddy glow about the sun by day has, so far as I have heen able to see, never really been long absent since attention was first drawn to it last autumn. I have now received a letter from Sydney, dated July 24, in which the writer says : "Since we have been in the Southern Hemisphere the sunsets have certainly had more striking colours, and on many occasions I have seen that peculiar magenta or mauve tint in the sky like aurora, only bluer in colour, while the sky has been very white just before sundown." The writer of the above is used to the look of the sun and sky, being an officer on board a mail steamer. I had suspected that absence of colour more or less in the sunsets here during our summer might be owing to the position of the sun rather than to any diminution in the quantity of vapour in the higher atmosphere, and had asked the writer of the above to note as he went south, in their winter, whether there was any increase in the colour of the after-glows, \&c., being led to think this might be the case from reading the report of $\mathrm{Mr}$. Neison, Director of the Natal Observatory, in which he speaks of having " first observed these phenomena in February 1883, from which time they increased in intensity until June, after which there was an interruption until the month of August." This led me to expect a return of strongly marked colour in our after-glows in autumn, increasing probably in intensity and duration during our winter months, when the weather is clear enough to see the sky.

Moira Place, Southampton, September 19

\section{The Diffusion of Species}

THE vast and altogether exceptional assemblage of Salpæ mentioned in NATURE (September I 1, p. 462) by the Duke of Argyll as having been observed by him whilst recently cruising in the Hebridean seas, was due, in all probability, to the extension in a north-easterly direction of the ordinary surface-curren of the Atlantic, or to an unusually long continuance of steady south-westerly wind, the effect of which would be to drive the superficial water of the Atlantic before it to the British coasts, and, with the water, the enormous multitudes of Salpæ which are occasionally to be met with in the latitude of the Canarie and Cape Verd Islands. ${ }^{1}$

During voyages to and from Bengal, viâ the Cape, in the good old days of sailing vessels, I repeatedly came across vast aggregations of these creatures; my attention having been specially called to them whilst engaged as I generally was for many hours by night as well as by day, in using a towing net from the stern ports for the capture of natural history specimens.

On my last voyage from Bengal in 1857 the ship sailed through some fifty or sixty miles of what the Duke aptly describes as Salpa soup, and which looked exactly like boiled tapioca. The quantity of Salpx present in a bucket of the sea-water was, at least, equal in volume to the volume of water, but then the bodies of the Salpæ themselves consist in reality of more than 90 per cent. of water. On the occasion referred to, almost the entire mass consisted of a small species of Salpa about an inch in length, but nevertheless large enough to render the bright

I As is well known, vast assemblages of Salpæ and kindred forms constantly occur at the surface in Arctic and Subarctic seas, during the prevalence of moderate weather: yellow digestive cavity of each, which is about the size of the smallcst pin's head, distinctly visible. This was invariably full of certain species of oceanic diatoms the endochrome of which imparted the yellow colour. It is worthy of remark that in the case of the Salpæ, as well as many other organisms holding a yet lower position in the animal scale, there undoubtedly exists a selective power which enables them to pick out certain kinds of food in the midst of a superabundance of different kinds.

In the tropical Atlantic and Indian Oceans also I have seen, during calms, immense numbers (though not to be compared with the gatherings of the smaller Salpæ) of the larger chain Salpæe. These sometimes attain a length of from 8 to Io inches, and have stomachs as large as a good-sized marble or hazel-nut.

But the most interesting assemblage of the lower forms of pelagic life was noticed by me about 200 miles from Ceylon, during a dead calm of four days' duration, when the sea was as smooth as a mirror, and undisturbed save by its never-ceasing majestic swell. Deep down, as far as the eye could penetrate, were to be seen numbers of brightly coloured water-snakes, delicately tinted "Venus's girdles," "Velellæ," and countless multitudes of those more minute living things which, though barely visible as mere specks to the unaided vision, are full of beauty and interest when observed under the microscope. Such a calm is a veritable pandemonium to the "skipper,"-to the naturalist it is a paradise.

September 14

I AM specially interested in the Duke of Argyll's letter on the above subject (p. 462), being a resident during nearly half the year in the most southern of the Hebrides. His Grace is so competent naturalist, and so accurate an observer, that I assume at once he had evidence which satisfied himself that an adder swam from Mull to Iona. Still I must be pardoned if I say that your readers have not been supplied with the proofs which have satisfied his Grace. A boy and girl in Iona, who, I presume, had never seen an adder in their lives, killed a creature in the sea there. Might it not have been an eel?

As regards distribution of species I may mention the following. In this island (Islay) we have multitudes of stoats but not a single weasel, while I am informed on trustworthy authority that in the neighbouring island of Colonsay there are many weasels but not a single stoat.

Sunderland House, Islay, September I8

\section{Shifting of the Earth's Axis}

IN the very interesting address of Prof. Young (NATURE, September 18, p. 50I) he refers to the variability of the earth's axis, and states that a change of $I^{\prime \prime}$ per century has been detected at Pulkowa, but that "the Greenwich and Paris observations do not show any such result." Now only last year, in the "Pyramids and Temples of Gizeh," I had (p, 126) noted that the Greenwich observations did appear to show a change, and that a change of the same amount and same direction as is stated by Prof. Young for Pulkowa; the observations of this century showing a decrease of $\mathbf{I}^{\prime \prime}$ of latitude per century, or with those of Maskelyne a decrease of $\mathbf{i}^{\prime \prime} 3^{8}$ per century.

This change I adduced as corroborating the result shown by four very accurate orientations of the earliest buildings, the Gizeh pyramids. These structures, whose errors are but a few seconds of angle, agree in standing as much as $4^{\prime}$ or $5^{\prime}$ to the west of the present north. This would imply a change of about $5^{\prime \prime}$ or $6^{\prime \prime}$ per century in the direction of long. $120^{\circ}$; a result quite comparable to the motion of $\mathrm{I}^{\prime \prime}$ or $\mathrm{I}^{\prime \prime} 44$ per century in long. $\mathrm{O}^{\circ}$ and $30^{\circ}$. Such a change might be effected by causes which are beyond our observation ; as, for instance, unbalanced ocean circulation equal to a ring of water only 4 square miles in section moving at a mile an hour across the poles. If this motion of 6 " per century in long. $120^{\circ}$ is still in action, we might now expect to find a change of about $5^{\prime \prime}$ in the meridian determined at the beginning of the Ordnance Survey, a ground of observation which should not be neglected.

Bromley, Kent

\section{Salmon-Breeding}

Mr. FrANCIS DAY's interesting communication last week (p. 488 ) on this subject is likely to attract more attention from biologists and pisciculturists than any other recently-ascertained fact in the natural history of the Salmonidx, and it opens the large ques- 